\title{
Two-Dimensional Modelling of Subsurface Magnetic Lithology in Sokoto Basin, Northwestern Nigeria
}

\author{
${ }^{1}$ Egwuonwu, G. N., ${ }^{2}$ Ezeh, O. C., ${ }^{3}$ Jegede, S. I., ${ }^{4}$ Umego, M. N. \\ ${ }^{1}$ Department of Physics and Industrial Physics, Nnamdi Azikiwe University, Awka, Anambra State, Nigeria gn.egwuonwu@ unizik.edu.ng \\ ${ }^{2}$ Nigerian Geological Survey Agency, Utako Abuja FCT, Nigeria tediksglobalservices@ gmail.com \\ ${ }^{3}$ Department of Physics, Faculty of Physical Sciences, Ambrose Alli University, Ekpoma, Edo State, Nigeria samidojegede@yahoo.com \\ ${ }^{4}$ Department of Physics, Chukwemeka Odimegwu Ojukwu University, Uli, Awka, Anambra State, Nigeria mn.umego@unizik.edu.ng
}

\begin{abstract}
Two dimensional (2D) modelling of the subsurface lithology in the subsurface of Sokoto Basin, north-western Nigeria has been carried out using the area's aeromagnetic map. The modelling was aimed at investigating the potentiality of the area for mineral exploitation especially hydrocarbon even as a sedimentary and marine environment. The Basin covers an estimated area of $59,570 \mathrm{~km}^{2}$ which falls within $0.5^{\circ}$ by $0.5^{\circ}$ in Nigeria national grid. Three survey straight lines trending NW-SE and cutting across some anomalous zones in the area's residual aeromagnetic map were selectively drawn for the modelling and interpretation. With the aid of GMSYS Software Version 2.5D, the two dimensional models of the subsurface sediments and basement rocks. The results of the modelling showed that the area characterized by Cretaceous sediment of single lithology in the range of about $250 \mathrm{~m}$ to $400 \mathrm{~m}$ thick. The resulting model also showed a magnetic basement characterised by various lithology of rugged topography, dipping north-westwards of the study area. The interpreted model of the basement comprises igneous rocks such as Gabbro, Granite, Andesite, Schists, Rhyolite, Pyroxenite, Phylites, and Esites. The sediment-filled troughs and depressions on the basement's surface suggest that they could be good targets for groundwater. Also, several solid minerals could be exploited based on the modelled multi lithology magnetic basement. However, the maximum depth to the basement troughs suggests that the requirements for formation of hydrocarbon have not been met in the area; therefore its exploitation is not feasible in the Basin.
\end{abstract}

Keywords: Two-Dimensional, Modelling, Magnetic, Lithology, Nigeria, 2D, subsurface.

\section{INTRODUCTION}

The search for subsurface condition(s) favourable for environment conducive for formation of certain minerals deposits and minerals deposits especially hydrocarbon is pivotal in geosciences. It is fundamental to concentrate on the location and potentials mineral deposition in any area if suspected to have hydrocarbon accumulation. Where a basin is found to be more convincingly suggestive of the deposits through preliminary geological and pilot geophysical survey(s), further geophysical studies are carried out to ascertain the economic potentiality of the deposits. Nigeria in West-Africa, has thrived positively for decades in its earning of foreign exchange from exploration and exploitation of hydrocarbon deposits mostly from its coastal and sub-coastal regions. Right from the pre-colonial era, businesses and the earning of foreign exchanges of the nation were generated mostly from oil and gas industry, economic reports in Nigeria for the past few decades have shown that about $70 \%$ of its Nigeria's capital revenue is drawn from the lucrative oil and gas sector (Reynolds, 2011). Due to the sector's high profitability in the resent years, the governments of Nigeria, indigenous economists and geoscientists have doubled efforts in investigating both the offshore and inland locations which suggest hydrocarbon deposition for plausible exploration. Hence, high resolution geophysical survey techniques have in recent times thrived for precise prospecting in oil and gas industries in Nigeria.

Sokoto Basin is a sedimentary basin, thus it is believed based on its geology that it can harbour both solid minerals and occurrence of hydrocarbon even as a marine environment. Some of the solid minerals already explored in the Basin are Gabbro, Rhyolite, Andesite and Phylite. The quest for exploiting suspected hydrocarbon deposits in Sokoto Basin is still vague to full comprehension by stakeholders although the solution is not a mirage to geological and geophysical experts in the country. Meanwhile, previous but recent studies about the occurrence and economic potentiality of hydrocarbon deposits in the Sokoto were required by the national indigenous economists for update with the government. Previous reconnaissance studies in the area suggested that the Basin has an apparent potential for oil and gas deposits. The studies suggested the need for detailed geophysical interpretation of the subsurface involving the use of seismic, micro gravity and magnetic methods. Particularly, the application of aeromagnetic survey technique for unveiling some of the subsurface characteristics has been more frequently recommended among several other precision 
ISSN (online): 2581-3048

geophysical prospecting techniques for pilot investigation of hydrocarbon. Aeromagnetic method of survey when used for mineral prospecting has the advantage of wide coverage within a very short time window in search for shallow and deep seated magnetic minerals. Due to the method's comparatively rapidity in applications, it is adequate for reconnaissance surveys before other high resolution geophysical techniques such as seismic reflection technique is applied (Reynolds, 2011). Regional and residual aeromagnetic field maps of suspected hydrocarbon formation locations are usually plotted in order to unveil the anomalies suggestive of the deposits enrichment. Aeromagnetic survey has been proven in its applications for location, shape, size, strike, burial depth, magnetic susceptibility and intrinsic magnetization of causative bodies in the earth interior (Nwosu, 2011). Thus, based on the foregoing assertions, this study is aimed at carrying out a 2D modelling of the subsurface magnetic lithology in Sokoto Basin using the study area's aeromagnetic survey residual map. The models would aid the delineation of the area's potentiality for solid minerals and hydrocarbons prospecting.

\section{THE STUDY AREA}

The study area (Figure 1) is Sokoto Basin; a part Iullemmeden Basin which occurs as a large synclinal Basin in north-western Nigeria. The Iullemmeden has Basin its centre at the north of Niamey in the republic of Niger (Obaje and Yusuf, 2013). Sokoto Basin lies between latitudes $10^{\circ} 30^{\prime \prime} \mathrm{N}$ and $14^{\circ} 00^{\prime \prime} \mathrm{N}$ and between longitudes $3^{\circ} 30^{\prime \prime} \mathrm{E}$ and $7^{\circ} 00^{\prime \prime} \mathrm{E}$ covering an area of about $59,570 \mathrm{~km}^{2}$ in Nigeria national grid. Sediments of the Basin were underlain unconformably by PreCambrian Basement and accumulated during four main phases of deposition.

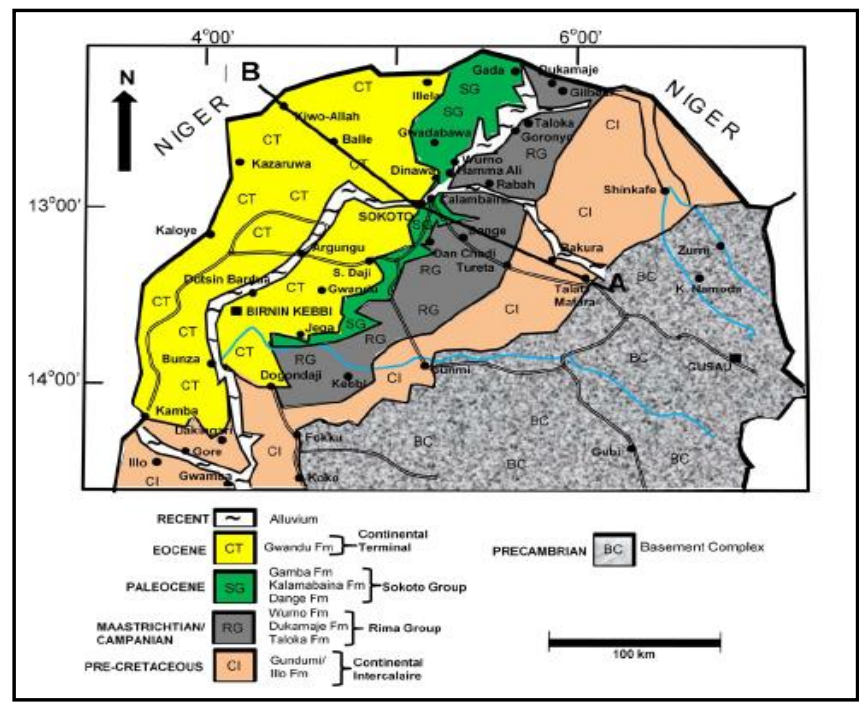

Figure 1: Geological Map of the Sokoto Basin (After Obaje and Yusuf, 2013)
The sediments were underlain unconformably by PreCambrian Basement and consist of Illo and Gundumi formations. Also, the sediments were made up of grits and clays which constitute the PreMaastrichtian "Continental Inercalaire" of West Africa. Sokoto Basin is known for being an area meant for sourcing some raw materials which were of economic significance.

Prior to this study, geophysical and geological studies carried out in the area were primarily targeted on determining its geological structures and the depositional environments, source rocks and hydrocarbon potentials. Particularly, there have been aeromagnetic researches in the Sokoto basin geared towards delineating anomalous zones: Umego (1990) carried out a gravity survey and aeromagnetic data analyses across the entire basin from which alignment of three linear belts of anomalous magnetic intensities were delineated. Egwuonwu (2000) carried out a detailed gravity and ground magnetic survey of Danger area within the Sokoto Basin, from the study, the structure and probable mode of emplacement of the causatives to the anomaly was determined as Schist. It is intended in this current study that using a state-of-the-art software package, the subsurface lithology of the study area within Sokoto Basin would be interpreted based on aeromagnetic residual data.

\section{METHODOLOGY}

The aeromagnetic data was sourced from a systematic regional airborne magnetic survey which was carried out at constant flight elevation of $10 \mathrm{~km}$ above mean sea level. A software namely Geosoft Oasis Montaj of Patterson Grant and Watson (PGW) of Canada Geosoft's Oasis Montaj software was used for processing the aeromagnetic data while the Geosoft Executables (GX) software which was also developed PGW was used for imaging of the study area, map preparation and its interpretation. Four $0.5^{\circ} \times 0.5^{\circ}$ high resolution total field intensity aeromagnetic map namely; sheets 29 (Dange), 30 (Dandi), 51 (Gunmi), and 52 (Anka) in the Sokoto sedimentary basin of scale 1:100,000 were obtained from the Nigerian Geological Survey Agency (NGSA).

The maps were digitized in .gbd format and were merged into one data file. Then data reduction, removal of heading error and lag, compensation for errors and the removal of the effects of time varying external fields of the International Geomagnetic Reference Field were carried out. These were followed by tie-lines, micro levelling, and gridding. The data file was imported and transformed into geographical format such that a $1^{0}$ x $1^{0}$ composite Total Magnetic Intensity (TMI) map (Figure 2) covering an area of $12,100 \mathrm{~km}^{2}$ was plotted. 
ISSN (online): 2581-3048

\section{IRJIET}

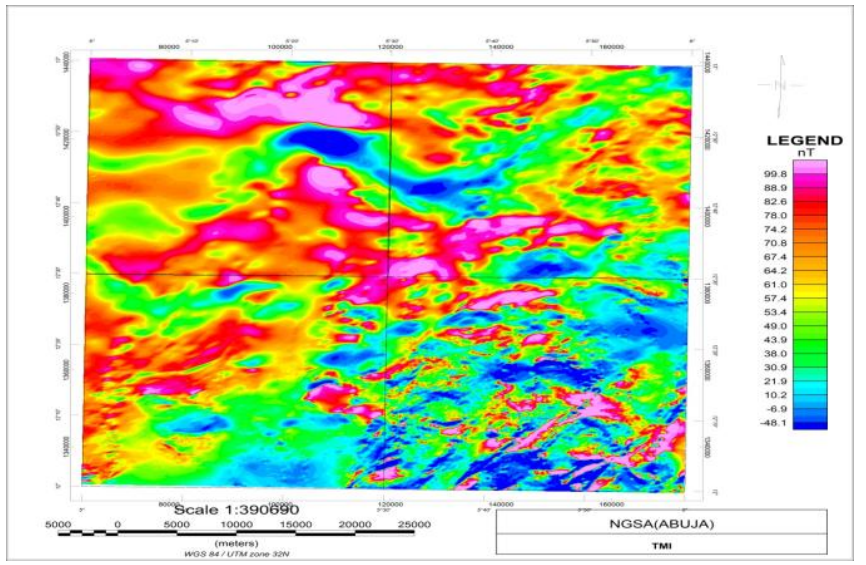

Figure 2: Total Magnetic Intensity (TMI) Map of the Study Area

The Total Magnetic Intensity (TMI) values in the map ranges between 32746.1 to $32888.7 \mathrm{nT}$ and is generally characterized by minor depressions scattered all over area. However, the map was considered in three parts for interpretation namely the southern, northern and central parts. The southern part of the map shows significantly lower magnetic intensity values than the other parts of the map. The northern part is significantly dominated by high magnetic intensity values while the central part between the southern and the northern parts is characterized by a relatively high magnetic intensity values compared with the south.

The TMI map shows the effects of all subsurface magnetic sources. Thus, in order to unveil better the anomaly occurrences as may be caused by the basement rock; the TMI was superimposed on the regional field that comes from larger and deeper sources.

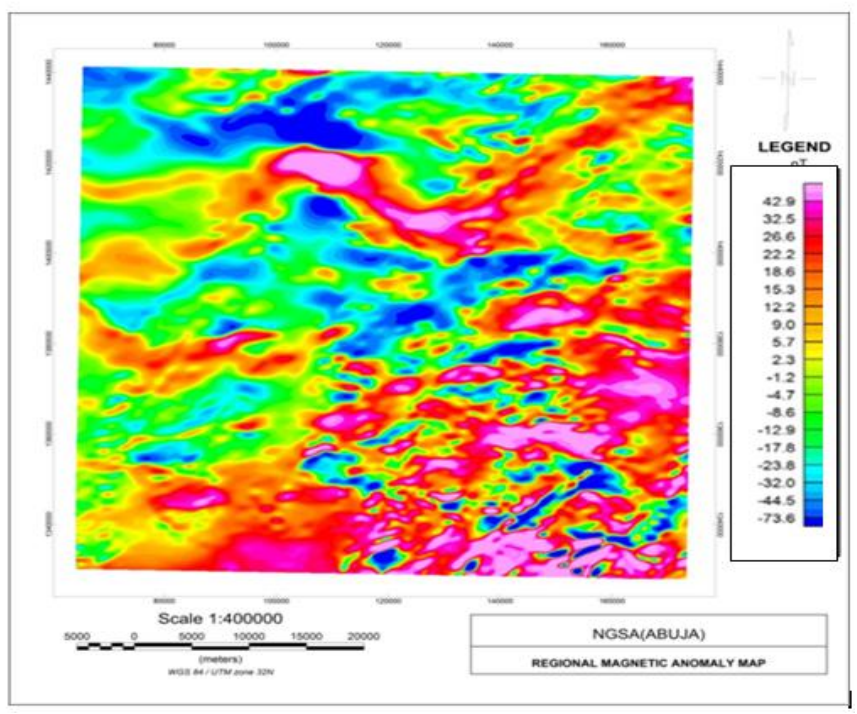

Figure 3: The regional map of the study area

The regional field was subtracted from the total magnetic field at grid cross points using the Butterworth filtering
Volume 5, Issue 1, pp 40-45, January-2021

https://doi.org/10.47001/IRJIET/2021.501005

method as a set control file to filter out short wavelength components from the residual anomalies. Using the regional and residual data separately, the regional field and the residual field maps were plotted respectively (Figures 3 and 4).

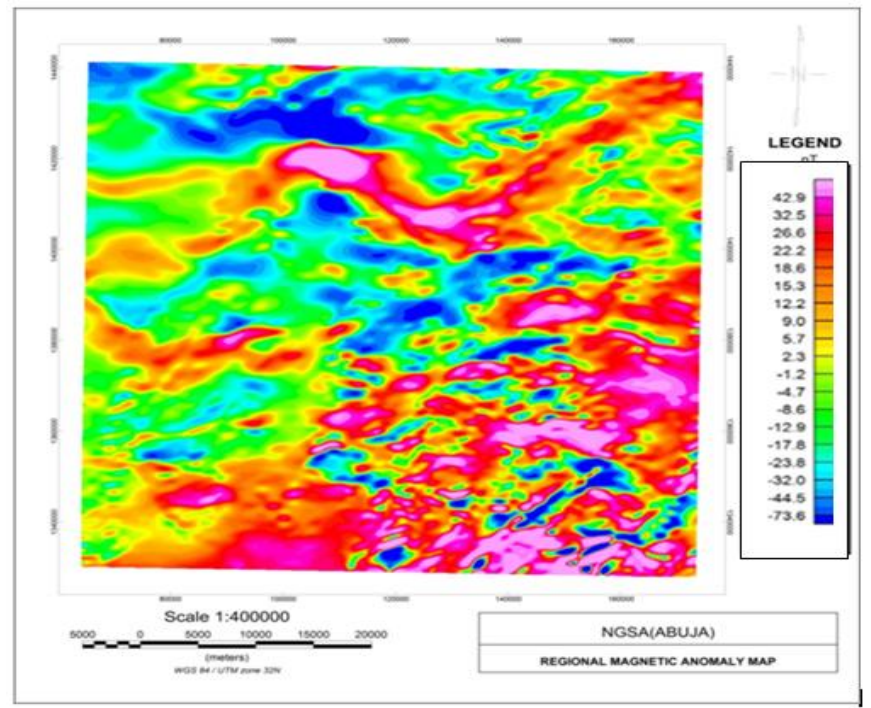

Figure 4: The Residual anomaly map of the study area

The regional magnetic intensity anomaly map in observed to show magnetic intensity range of values from $32795.2 \mathrm{nT}$ to $32889.1 \mathrm{nT}$. This range is seen to show decrease from the southern to northern zone of the map indicating the thickening of the sediments south- northwards. On the residual map was observed some prominent anomalies which were noted and marked for interpretation. The sources of the residual anomalies are more reliable subsurface causatives of the model lithology of the subsurface than the sources of TMI. The residual map shows a number of highs and lows of magnetic anomalies with various amplitudes and frequencies. This suggests that the basement surface of the area most probably comprises rocks of various values of magnetic intensity.

\section{DATA PROCESSING AND RESULTS}

In order to delineate the causative lithology that has yielded the anomalies, three profiles lines trending NW-SE were selectively drawn to cut across the anomalies shown in the residual map for interpretation. The systematic approach of selecting profiles was adopted in order model the rocks causative to the anomalous zones in the residual map plausibly.

The three profile lines were labeled Profile 1(P1); drawn across the southern anomalous part of the study area, Profile 2 (P2); drawn diagonally across the central part of the study area and Profile 3 (P3) drawn across the northern anomalous part of the study area respectively (Figure 5). 
ISSN (online): 2581-3048

\section{IRJIET}

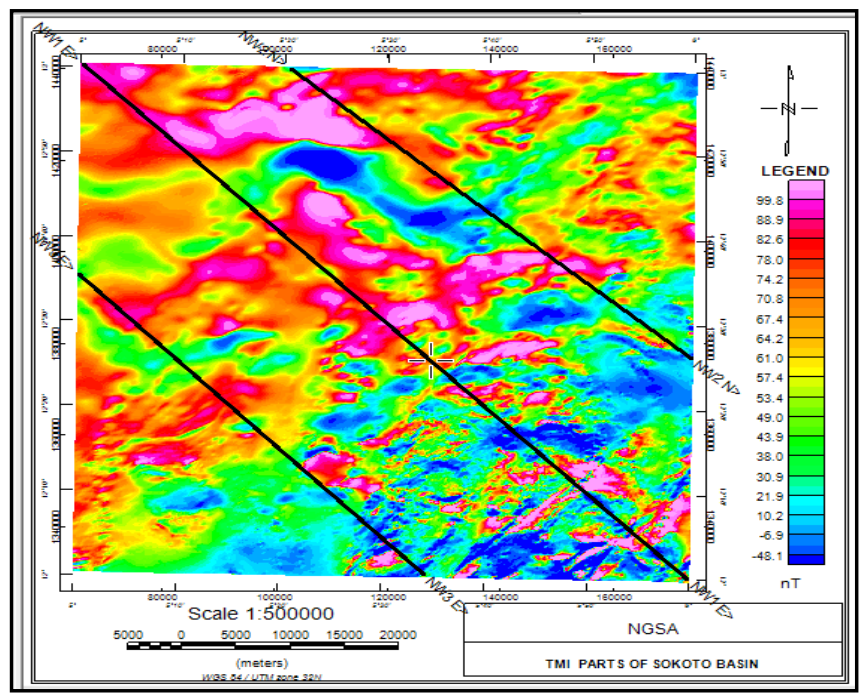

Figure 5: The Original Grid of the TMI with Some Selected Profiles

With the aid of software namely GM-SYS 2.5D, 2D models of the subsurface underlying the lines were delineated in order to determine the content of the signatures from the basement causative to the magnetic field variations. The software provided an easy-to-use interface for interactive manipulation and creation of the models. Magnetic Susceptibility values of the causative rocks (Table 1) were the principal characteristic s of the rocks used for the estimation of the Lithologic models obtained in the 2D modelling.

Table 1: The Magnetic Susceptibility Values of Modelled Lithology

\begin{tabular}{|c|c|}
\hline Lithology & Magnetic Susceptibility Values (cgs) \\
\hline Igneous Rocks & $4.201 \times 10^{-3}$ \\
\hline Pyroxenite & $3.101 \times 10^{-3}$ \\
\hline Rhyolite & $2.501 \times 10^{-3}$ \\
\hline Schist & $5.000 \times 10^{-5}$ \\
\hline Granite & $1.000 \times 10^{-2}$ \\
\hline Gabbro & $3.001 \times 10^{-3}$ \\
\hline Garnet Schist & $5.510 \times 10^{-4}$ \\
\hline Phylite & $2.751 \times 10^{-3}$ \\
\hline Andesite & $1.000 \times 10^{-6}$ \\
\hline
\end{tabular}

Source: (Adetona et al., 2006)

In the process of the modelling, the software was manipulated to calculate the difference between calculated data and the observed data hence, the minimum difference between the observed and the calculated fields were considered as the best fit model for the profiles respectively. The 2D models obtained from P1, P2 and P3 are shown in Figures 6,7 and 8 respectively. The models showed the responses of magnetic field to geologic causative bodies in the subsurface. The user friendly standard of the GM-SYS software was such that the speed of calculation of the magnetic response from the $2 \mathrm{D}$ models was sufficiently rapid such that the interpretation process offered the user allowance to quickly test alternative solution. The models represent the lithologies in the basement underneath the sedimentary layer
Volume 5, Issue 1, pp 40-45, January-2021

https://doi.org/10.47001/IRJIET/2021.501005

which are causatives to the variations of the magnetic intensity values used for plotting the residual anomaly map.

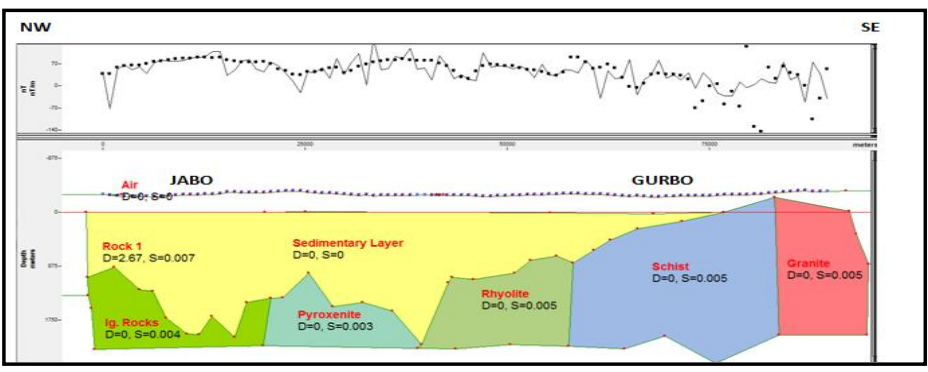

Figure 6: Profile 1 model

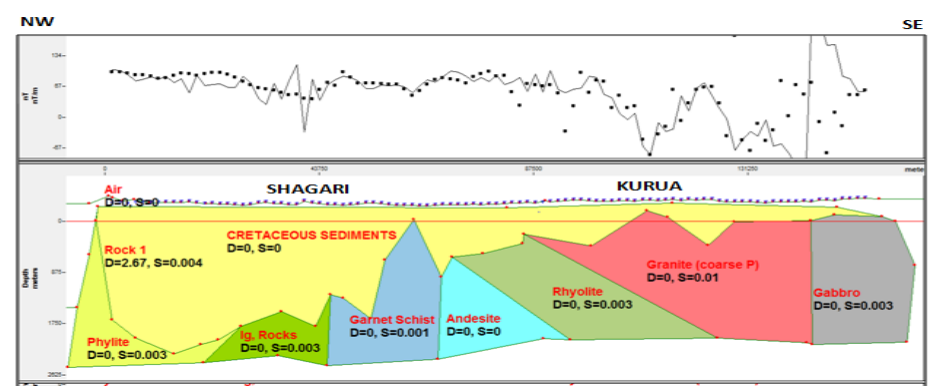

Figure 7: Profile 2 model

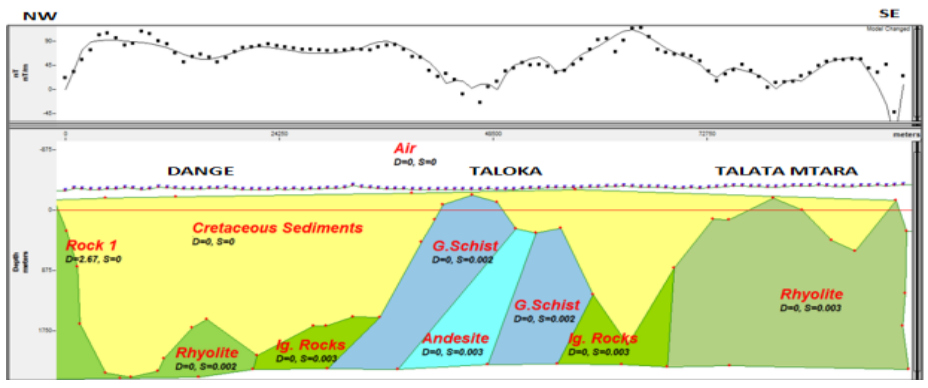

Figure 8: Profile 3 Model

\section{DISCUSSION}

Profile 1 (Figure 6) is a NW-SE 2D model of the southern part of the study area. The model plot is dimensioned about 90 $\mathrm{Km}$ by $2.2 \mathrm{Km}$ in length and maximum depth of probe respectively. The profile is characterised by low sedimentation traversing through Jabo and Gurbo towns. The maximum thickness of sediment is about $2.0 \mathrm{~km}$ which falls within sheet no. 51 (Gunmi). The subsurface sedimentation along the P1 shows a gradual decrease towards the southeast part of it and that the basement topography is undulating. The modelling shows several blocks of various lithologies such as Pyroxenite, Rhyolite, Schist and Granite which were according to their variation of magnetic susceptibly values. It is observed that Schist has the highest mass in the magnetic basement rock models.

Profile 2 (Figure 7) show the longest of all the three profiles with approximated length of $155 \mathrm{~km}$. It also oriented 
ISSN (online): 2581-3048

in NW-SE trend passing through Shagari and Kurua at the central part of the study area. The best fit of the modelling showed maximum depth of probe $2.5 \mathrm{Km}$. The sedimentation thickening is observed to be on the increase from southeastern side of it through Kurua where it is shallow to the north-western of it through Shagari where its maximum thickness is about $2.2 \mathrm{~km}$. The deepest occurrence of the sediments along the profile is observed around sheet No. 29 (Dange). The lithology of the subsurface obtained in the 2D modelling includes Phylite, Garnet, Schist, Rhyolite, Granite and Gabbro just as obtained from profile 1. Of all the causative rocks in the profile, coarse granite is observed as the most massive of the lithology formations.

Profile 3 model (Figure 8) obtained is approximately $96 \mathrm{~km}$ long having its maximum depth of probe about $2.4 \mathrm{Km}$. Its model plot is The profile also trends NW-SE through Dange town closer to NW, through Taloka town to Talata Mafara town at the southeastern end of it. The maximum sedimentation thickness of the profile is about $2.1 \mathrm{~km}$ around sheet 29 (Dange) and sheet 30 (Dandi) showing that the basement is deepest around Dange town. Its basement topography is rugged with its shallowest depths at Taloka and Talata Mafara towns. The lithology of the subsurface obtained from the 2D modelling are also igneous which includes Andesite, Garnet Schist, Rhyolite. The Rhyolite is the most massive of the magnetic basement along this profile.

The interpretation of magnetic data was based on the knowledge of rock-magnetic properties of the study area such as the rocks magnetic susceptibility and remanent magnetization. An interpretable profile was obtained using a digital data set. Therefore, the basement feature from the model plots reveal a form of N-S trending troughs and ridges located mostly in the N-W part of the study area. The undulating shape of the basement suggests a gentle folding of the subsurface rocks. It may therefore be concluded that the basement rocks underlying the basin have been gently deformed showing anticlines and synclines.

Since the synclines and other depressions are filled with more than the average thickness of the sediments, they are therefore considered to be probable targets for groundwater exploration. The gradual or low gradient of the depth topography of sediment-basement boundary is suggestive of a gradual decrease in the basement depth from the basin towards the boundary (Sambo, 1994; Umego, 1990). The map suggests that the sedimentary thickness of the Sokoto Basin increases from southern to northern part of the area. However, the map reveals major magnetic divisions which may not be recognised in the field if small areas are mapped.

\section{CONCLUSIONS}

The residual anomaly contour map of the Sokoto Basin displayed various magnetic highs and lows with different magnetic intensities. The interpretation has shown various compositions of rocks which identified based on their magnetic susceptibility values. The model basement rocks include; Gabbro, Granite, Andesite, Schists, Rhyolite, Pyroxenite, Phylites, and Esites. Comparing this with the number of magnetic minerals mapped by Bonde et al (2014) wherein only clay and limestone were delineated, more detailed models were delineated in this study. Several depressions or variations in the sedimentation depths into shallow synclines and anticlines in the Basin suggest that there are probable potential zones good for groundwater exploitation. The modelled magnetic data has shown that it is a representation of irregular basement floor resulting from gentle folding of the basement rocks along a general $\mathrm{N}-\mathrm{S}$ axis. The gently undulating basement is of average elevation varying from 250 to $400 \mathrm{~m}$ above sea-level. However, this depth range is comparably insufficient for formation of hydrocarbon deposits in the coastal and marine environments in Nigeria.

\section{REFERENCES}

[1] Adetona A. A, Udensi E.E and Agelaga A. G. (2006). Determination of Depth to Buried Magnetic Rocks under the Sokoto Basin, Nigeria, Using Aeromagnetic Data. Nigerian Journal of Physics. 19(2) (2007).

[2] Burger, H.R., (1992). Exploration Geophysics of the Shallow Subsurface, Prentice and Hall, 489.

[3] Egwuonwu G.N., (2000). Detailed Gravity Study of the Dange Anomaly in Sokoto State, Nigeria. Unpublished Msc Thesis Ahmadu Bello University, Zaria, Nigeria.

[4] Gunn, P.J., (1997). Quantitative methods for interpreting Aeromagnetic Data. Journal of Australian Geology and Geophysics. 17(20):105-113.

[5] Sambo, S.O, (1994). Spectral analysis and interpretation of aeromagnetic anomalies over sokoto basin, Nigeria. Unpublished M.Sc Thesis Ahmadu Bello University, Zaria, Nigeria.

[6] Fairhead, J.D., Williams, S.E. and Flanagan, G., (2004). Testing Magnetic Local Wavenumber Depth Estimation Methods using a complex 3D Test Model. SEG Annual Meeting Denver, Extended Abstract.

[7] Kogbe, C. A, (1981) Cretaceous and Tertiary of the Iullemmeden Basin of Nigeria (West Africa).Cretaceous Res 2:129-186.

[8] Mushayandebvu, M.F. Lesur, V., Reid, A.B. and Fairhead, J.D., (2004). Grid Euler deconvolution with 
ISSN (online): 2581-3048

Volume 5, Issue 1, pp 40-45, January-2021

constraints for 2D structures. Geophysics, 69(2):489496.

[9] Nwosu, (2011), Analyses of Aeromagnetic Data over some parts of Middle Benue Trough Using Spectral Analysis and Empirical Depth Rule. An Unpublished M.Sc work, Nnamdi Azikiwe University, Awka, Nigeria.

[10] Obiora, D.N. (2006) Comparative Study of Graphical Methods and Velocity Analysis of 2-D Seismic
https://doi.org/10.47001/IRJIET/2021.501005

Reflection Data with Application to Niger Delta. Pacific Journal of Science and Technology, 7(2): 204 $-210$.

[11] Reynolds, J.M. (2011). An Introduction to Applied and Environmental Geophysics, John Wiley \& Sons Ltd, Chichester, 2nd Ed., 712 pp.

[12] Sheets 29 (Dange), 30 (Dandi), 51 (Gunmi), and 52 (Anka).

\section{Citation of this Article:}

Egwuonwu, G. N., Ezeh, O. C., Jegede, S. I., Umego, M. N., "Two-Dimensional Modelling of Subsurface Magnetic Lithology in Sokoto Basin, Northwestern Nigeria" Published in International Research Journal of Innovations in Engineering and Technology - IRJIET, Volume 5, Issue 1, pp 40-45, January 2021. Article DOI https://doi.org/10.47001/IRJIET/2021.501005 